\title{
Commentary to the articles of M. Stier (Normative preconditions for the assessment of mental disorder) and T. Schramme (On the autonomy of the concept of disease in psychiatry)
}

\author{
Gerald Ulrich * \\ Klinik für Psychiatrie und Psychotherapie, University Medicine-Charité, Universitätsmedizin Berlin, Berlin, Germany \\ *Correspondence: gerald.ulrich@yahoo.de
}

Edited by:

Sebastian Muders, Universität Zürich, Switzerland

Keywords: biological or somatic psychiatry?, biologism or somatologism?, materialistic monism vs. epistemic dualism (or dualism of aspects)?, nominalistic definitions, biological natural science and humane discipline

\section{A commentary on}

Normative preconditions for the assessment of mental disorder

by Stier, M. (2013). Front. Psychol. 4:611. doi: 10.3389/fpsyg.2013.00611

On the autonomy of the concept of disease in psychiatry

by Schramme, T. (2013). Front. Psychol. 4:457. doi: 10.3389/fpsyg.2013.00457

Both authors agree that:

\begin{abstract}
"Mental illness is not reducible to brain illness, even when mental phenomena have their basis in the brain" (Schramme, 2013, p. 8) and

"...because of the normative nature of psychiatry, mental disorder cannot be completely reduced to neuronal or molecular processes. [...] A mental state as such may well be reducible to the brain, but determining whether this very state is (part of) a disorder or not, is nothing the brain sciences can do." (Stier, 2013, p. 8).
\end{abstract}

Therewith the authors deny the tacit assumption according to which disease in its proper sense can only be somatical but never psychic. This posit, which was propagated under the common term of "Somatosepostulat" by the German psychiatrist Kurt Schneider (Schneider, 1950) who dominated the post-war psychiatry. Strangely enough the content of Schneider's posit was later on ascribed to a falsely abridged citation of Griesinger according to which mental diseases were nothing but brain diseases (Griesinger, 1861). In fact he stressed in addition that mental states ("Seelenzustände") may not be reduced to functional disturbances of the brain ("Funktionszuständen des Gehirns").

Definitely no one who is familiar with the second edition of Griesinger's textbook would call this distinguished author to witness psychiatry as a special kind of neurology. Moreover, if a mental disease is nothing but a neurological or a somatic disease respectively, it was logical mandatory to speak of "Somatic Psychiatry." Therefore it is disconcerting that this term is absolutely unfamiliar. Instead, Schneider's posit goes under the disguise of the semantically inappropriate term of "Biological Psychiatry." Following this rational way of thought, the unanswered question arises what actually could be intended by the title of the reviewed symposium "Biologism within Psychiatry?" (Biologismus in der Psychiatrie?) whereas-strictly speakingone ought to use the unusual or even inexistent term of "Somatologism."

By the way, to the present author whose duty consisted only to comment on a freely chosen article (out of six) it is cloudy that neither in the workshop nor in any one of the later on prepared articles an answer was searched for the core issue contained in the workshop-title whether psychiatry suffers from biologism (or not). This seemed to be avoided like a hot potato since it would have implied a debate on the outstanding semantics of "biological," biologistical or "somatical."
Schramme states, that the recent publication of DSM V should give occasion for the underlying philosophical aspects of the language of mental disorder to make itself clear within the psychiatric trade. He criticizes DSM IV for using the term "mental disorders":

\begin{abstract}
"Mental implies a Cartesian view of the mind-body problem that minds and brains are separable and entirely distinct realms, an approach that is inconsistent with modern philosophical and neuroscientific views." (Schramme, 2013, p. 8).
\end{abstract}

One cannot but agree that the progress of psychiatry depends on a logical and semantical consistent terminology. But it is just as disputable that this aim can be reached by simply eliminating the colloquial term "mental" being used as a synonym of "psychic" and/or an antonym of "somatic." Why should the concept of mental illness be autonomous from somatic medicine, as Schramme claims?

The real problem to be solved is not an outdated Cartesian view of substance dualism, being scarcely advocated by any of the contemporary psychiatrists, but the prevailing materialistic monism or eliminative reductionism (e.g., Paul and Patricia Churchland, Armstrong, Quine Ryle, Skinner, Crick etc.) which is being camouflaged by the term "biology/biological" being ill-posed because opposite to the sense intended.

There is only one epistemological solution which goes back to Spinoza (1890). 
Among the contemporary exponents of this solution the best known is Habermas (Habermas, 2004) who prefers to speaks of "Epistemic dualism." Another notion of this concept which dispels the myth of the unsolvable mind-brain problem is that of “Aspektdualismus" (Ulrich, 1990, 1997, 2006a,b, 2013).

About a decade ago a German psychiatric chair holder wrote about his vision of an integrated clinical-neuroscientific field with psychiatry as a special focus but no longer existing as an autonomous field (Maier, 2002). The Psychiatrist was redefined as a Clinical Neuroscientist or Clinical Psychopharmacologist.

Recently the director of a renowned Max-Planck-Institute for Psychiatry confessed in an interview that he surely was a better chemist than psychiatrist (Holsboer, 2005). By an editorial, entitled: "Are we still in need of psychiatry as a special field within medicine?" Ulrich (Ulrich, 2006a) demanded that psychiatrists should discourage any attempt to abandon psychiatry as a distinct discipline. He referred to the demand of Aspect Dualism being valid for medicine as a whole. Accordingly, "either-or interrogations" have to be replaced by "as-well-as" ones. Thus, it was undue to beg the question whether a hysteria is a brain disease or a psychological disease, or whether a depressive disorder is a biochemical or a psycho-social disorder. Such nominalistic definitions are equally misguided as the question whether an altarpiece should be labelled as an antique or a sacred object. By a recent monograph Ulrich defined Psychiatry both as a Biological Natural Science and a Humane Discipline (Ulrich, 2013).

\section{REFERENCES}

Griesinger, W. (1861). Die Pathologie und Therapie der psychischen Krankheiten. 2. Umgearbeitete und Sehr Vermehrte Aufl. [Pathology and Therapy of Psychic Diseases, 2nd Edn.]. Stuttgart: Krabbe.

Habermas, J. (2004). Die Freiheit, die wir meinen, (gekürzte Fassung der Dankesrede zur Verleihung des Kyoto Preises). [The Freedom we mean, (shortened version of the speech of thanks for the Kyoto Prize)]. Der Tagesspiegel. Available online at: http://www.tagesspiegel.de/kultur/die-freiheitdie-wir-meinen/562620.html. [Accessed May 28, 2013].

Holsboer, F. (2005). Interview mit A. Franz: Chemie für die Seele. [Interview with A. Franz: Chemistry for the soul]. Die Zeit. Available online at: http://www.zeit.de/2005/41/P-Holsboer (Accessed January 09, 2014)

Maier, W. (2002). Leserbrief zum Beitrag von $\mathrm{H}$. Häfner: psychiatrie als Beruf. [Reader's letter to the article of H. Häfner: psychiatry as a profession]. Nervenarzt 73, 96-99. doi: 10.1007/s115002-8154-x

Schneider, K. (1950). Klinische Psychopathologie [Clinical Psychopathology]. Stuttgart: Thieme.

Schramme, T. (2013). On the autonomy of the concept of disease in psychiatry. Front. Psychol. 4:457. doi: 10.3389/fpsyg.2013.00457

Spinoza, B. de. (1890). Die Ethik [Ethics]. Leipzig: P. Reclam jun.

Stier, M. (2013). Normative preconditions for the assessment of mental disorder. Front. Psychol. 4:611. doi: 10.3389/fpsyg.2013.00611

Ulrich, G. (1990). Was unterscheidet und was verbindet Somatotherapie und Psychotherapie? Oder, worauf gründet sich das dualistische Denken in der Medizin und wie lässt es sich überwinden?
[What differentiates and what connects somatotherapy and psychotherapy. Or, what is the basis of dualistic thinking in medicine and how can it be overcome?]. Fund. Psychiatr. 4, 132-136.

Ulrich, G. (1997). Biomedizin-Die Folgenschweren Wandlungen des Biologiebegriffs. [BiomedicineThe Weighty Conversions of the Concept of Biology]. Stuttgart: Schattauer.

Ulrich, G. (2006a). Brauchen wir die Psychiatrie noch als eigenständiges Fach? [Are we still in need of psychiatry as a special field within medicine?] (Editorial). Psychiatr. Prax. 33, 255-257. doi: $10.1055 / \mathrm{s}-2005-915460$

Ulrich, G. (2006b). Das epistemologische Problem in den Neurowissenschaften und die Folgen für die Psychiatrie. [The epistemological problem in the neurosciences and the consequences for psychiatry]. Nervenarzt 77, 1287-1300. doi: 10.1007/s00115-006-2099-6

Ulrich, G. (2013). Psychiatrie: Biologische Naturwissenschaft und Geisteswissenschaft. [Psychiatry: Biological Science and Humane Discipline]. Tübingen: dgvt-Verlag.

Received: 09 January 2014; accepted: 27 January 2014; published online: 20 February 2014.

Citation: Ulrich $G$ (2014) Commentary to the articles of M. Stier (Normative preconditions for the assessment of mental disorder) and T. Schramme (On the autonomy of the concept of disease in psychiatry). Front. Psychol. 5:112. doi: 10.3389/fpsyg.2014.00112

This article was submitted to Theoretical and Philosophical Psychology, a section of the journal Frontiers in Psychology.

Copyright (c) 2014 Ulrich. This is an open-access article distributed under the terms of the Creative Commons Attribution License (CC BY). The use, distribution or reproduction in other forums is permitted, provided the original author(s) or licensor are credited and that the original publication in this journal is cited, in accordance with accepted academic practice. No use, distribution or reproduction is permitted which does not comply with these terms. 